\title{
Information Seeking Behavior of Tribal Guava Farmers in Sawai Madhopur District of Rajasthan, India
}

\author{
K.C. Sharma ${ }^{1 *}$, Seeta Bijarniya ${ }^{1}$, Rajendra Junjadiya ${ }^{1}$ and Shalini Sharma ${ }^{2}$ \\ ${ }^{1}$ Agriculture Extension, SKNAU, Jobner Jaipur-303329, India \\ ${ }^{2} \mathrm{BHU}$, Varanasi, UP, India \\ *Corresponding author
}

\section{A B S T R A C T}

\begin{tabular}{|l|}
\hline K e y w o r d s \\
Information seeking \\
behavior, Mass media, \\
Guava farmers, \\
Orchards, Association, \\
Independent variables, \\
Social participation.
\end{tabular}

The present study was undertaken in the year 2013 in Sawai Madhopur District of Rajasthan in order to know the information seeking behavior of tribal guava farmers and to find out the association of selected independent variables with the information seeking behavior of guava farmers. A sample of 100 guava farmers selected randomly from 10 villages having highest area under guava plantation. The study leads to the conclusion that majority (76 per cent) of both type of guava farmers i. e. peripheral and distant were having medium level of information seeking behavior followed by 13 per cent having low and 11 per cent were having high level of information seeking behavior. The " $Z$ " value between the scores of the information seeking of the peripherals and distant guava farmers was -0.74 , which was non-significant. This shows that there was no significant difference between the peripherals and distant guava farmers in their information seeking behavior. The study also reveals that there was significant association between the information seeking behavior of total guava farmers and their age, education level, social participation, size of land holding, farm power, innovation proneness and annual income, similarly nonsignificant association was found between the information seeking behiviour with the family size and farming experience of the guava farmers.

\section{Introduction}

Modernization of Indian agriculture greatly depends on creation of farm technology and its dissemination. India is well equipped in Agriculture technology but full use of available technology is not being made in many areas of the country. By and large the research remain unused in laboratories and the research does not reach to the farmers. Besides this agriculture technology is changing at an increasing rate. Hence it is necessary to select quick system of communication to keep farmers in tune with the fast developments in research technology.
As majority of population in our country is engaged and depend on agriculture, we have to access and make available latest technology which turns agriculture to be efficient. Mass media plays an important role in increasing better functioning and creates awareness about new technologies.

Farmers seek information from trainings, conferences, exhibitions, campaigns, bulletins, seminars, radio, television, newspapers, friends and neighbors, research stations, KVKs, village extension workers etc. 
for enhancing agriculture production. It is also said that there are important means to fill the communication gap between the lab and the farm. These have brought the farmers and scientists closer to understand the suitability of technology in time with farmer's perspectives.

The personal characteristics of Guava farmers play an important role in acceptance of new technology from any source or channel. Today is the era of information explosion. Innumerable information is generated, synthesized and disseminated at every movement. Information technology has revolutionsed the transfer of information through new ways i.e. internet, e-mail etc. Information from any part of the world could be made available through IT thereby changing the world into global village. Therefore, the farmers should also be equally privileged to get informed of farm related information without delay. Keeping all these points in mind the present study "variables affecting the information seeking behaviour of the tribal Guava farmers in Sawai Madhopur district of Rajasthan" was carried out.

\section{Materials and Methods}

The present study was undertaken in Sawai Madhopur district of Rajasthan in the year 2013. Sawai Madhopur tehsil was selected purposely due to having highest number of orchards, area and production of Guava fruits in the district. The guava orchards in the area were mainly owned by Meena tribals. A list of all guava growing villages was prepared, out of which 10 villages having highest area under guava cultivation were selected randomly for the study purpose. From the selected villages, a sample of 100 guava farmers was selected by random sampling technique for the study purpose in such a manner that the number of guava growers selected was proportional to the total number of guava famers of the respective villages. An interview schedule consisting of measuring devices of dependent and independent variables along with the face data of guava farmers was used for collecting response of the guava farmers. The information seeking behavior of the guava farmers was measured by adding the sources of all component of information seeking behavior viz. extent of use of different sources and channels, credibility of different sources and channels, extent of contact to different extension functionaries, extent of exposure to different media. The data were collected by personal interview method, the date collected were classified, tabulated and inference were drawn after subjecting the data to appropriate statistical analysis which led to the following major findings.

\section{Results and Discussion}

\section{Information seeking behavior of the guava farmers}

The information seeking behavior of different sources and channels of agriculture information was calculated by summing the guava growers scores of 'extent of use of information sources and channels', 'extent of exposure to different media', of each of the respondent. The respondents were then categorized into three categories namely; 'low information seeking behavior', 'medium information seeking behavior' and 'high information seeking behavior' by using mean (192.02) and standard deviation (15.09). The information seeking behaviour of peripheral and distant guava growers has been presented in Table 1.

The data in Table 1 explains that majority of both types of guava growers (76.0 per cent) were having medium level of information seeking behaviour followed by 13.0 per cent having low and 11.0 per cent were having high level of information seeking behavior. 
The data in table also shows that majority of the peripheral guava growers (85.11 per cent) were having medium level of information seeking behavior followed by 12.76 per cent peripheral guava grower having low level of information seeking behavior and only 2.13 per cent peripheral guava growers were having high level of information seeking behavior.

In case of the distant guava grower 67.92 per cent were having medium level of information seeking behavior followed by 18.87 per cent were having high level of information seeking behavior and 13.21 per cent were having low level of information seeking behaviuor.

The analysis of data further indicates that the ' $Z$ ' value between the scores of the information seeking of the peripheral and distant Guava farmers was -0.74 which was non-significant. Hence the null hypothesis was accepted. This shows that there was no significant difference between the peripheral and distant Guava farmers in their information seeking behavior. The findings are in line with the findings obtained by Dhayal et al., (2009), Sharma and Nitharwal (2011), Meena (2012) and Meena et al., (2013).

Association of the selected independent variables with the information seeking behaviour of guava farmers

The association between the information seeking behaviour of guava farmers and selected independent variables viz. age, education level, social participation, size of land holding, farm power, family size, farming experience, innovation proneness and annual income were measured by computing "coefficient of correlation (r)". The data have been presented in Table 2. A critical examination of Table 2 revealed that the guava growers education level, social participation, size of land holding, farm power, innovation proneness and annual income were found positively and significantly correlated with their information seeking behaviour at 0.01 level of probability, while the age of the guava farmers was found negatively and significantly correlated with their information seeking behaviour at 0.05 level of probability. Hence the null hypothesis showing that there is no significant association between the information seeking behaviour of the guava farmers with their age, education level, social participation, size of land holding, farm power, innovation proneness and annual income was rejected and alternate hypothesis was accepted. This leads to the conclusion that there is a significant association between the information seeking behaviour of the guava farmers and their age, education level, social participation, size of land holding, farm power, innovation proneness and annual income.

The family size of the guava growers was positively and non-significantly associated with their information seeking behavior, whereas their 'farming experience' was negatively and non-significantly associated with their information seeking behaviour. Hence, the null hypothesis showing that there is no significant association between the information seeking behaviour of the guava growers and their family size and farming experience accepted. A critical examination of the data presented in table also revealed that the peripheral guava growers age, education level was found negatively and significantly correlated with their information seeking behaviour at 0.01 level of probability. Their farm power was found positively significant at 0.05 level of probability. This leads to the conclusion that there is significant association between the information seeking behaviour of the peripheral guava growers and their age, education level and farm power. 
Table.1 Distribution of peripheral and distant guava farmers according to their information seeking behavior

\begin{tabular}{|c|c|c|c|c|c|c|c|}
\hline $\begin{array}{l}\text { Levels of } \\
\text { information } \\
\text { seeking behavior }\end{array}$ & $\begin{array}{l}\text { Per } \\
\text { farı }\end{array}$ & Guava & $\begin{array}{l}\text { Dis } \\
\text { farr }\end{array}$ & Guava & $\begin{array}{l}\text { Tota } \\
\text { farm }\end{array}$ & Guava & 'Z' value \\
\hline & F & $\%$ & $\mathbf{F}$ & $\%$ & $\mathbf{F}$ & $\%$ & \\
\hline $\begin{array}{l}\text { Low } \\
\text { (Below 181.93) }\end{array}$ & 6 & 12.76 & 7 & 13.21 & 13 & 13.00 & \multirow{4}{*}{$-0.74 \mathrm{NS}$} \\
\hline $\begin{array}{l}\text { Medium (From } \\
181.93 \text { to 212.11) }\end{array}$ & 40 & 85.11 & 36 & 67.92 & 76 & 76.00 & \\
\hline $\begin{array}{l}\text { High } \\
\text { (Above 212.11) }\end{array}$ & 1 & 2.13 & 10 & 18.97 & 11 & 11.00 & \\
\hline Total & 47 & 100 & 53 & 100 & 100 & 100 & \\
\hline
\end{tabular}

$\mathrm{X}=197.02, \sigma=15.09, \mathrm{NS}=$ Non significant

Table.2 Association between the information seeking behaviour of guava farmers and selected independent variables

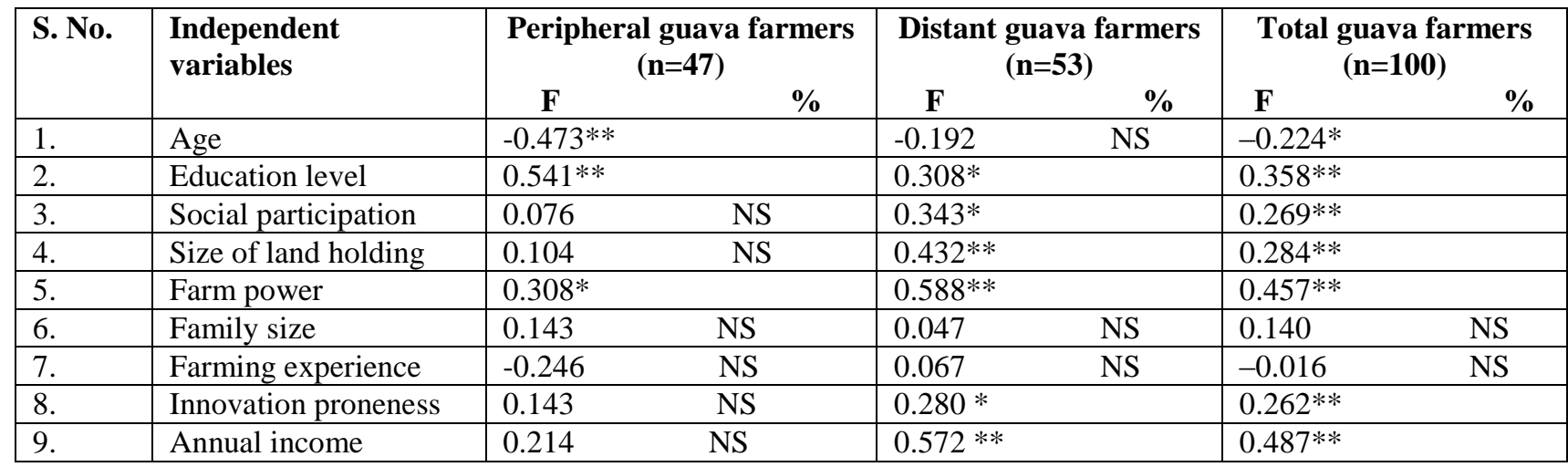

$*$ Significant at 0.05 level of probability, NS= Non-significant, **Significant at 0.01 level of probability

While their social participation, size of land holding, family age, farming experience, innovation proneness and annual income were non-significantly associated with the information seeking behaviour. From these observations it is concluded that there is no significant association between the information seeking behaviour of the peripheral guava growers and their social participation, size of land holding, family size, farming experience, innovation proneness and annual income.

A critical examination of the data presented in Table 2 also revealed that the distant guava growers education level, social participation and innovation proneness were positively and significantly correlated at 0.05 level of probability and their size of land holding, farm power and annual income were positively and significantly correlated at 0.01 level of probability with the information seeking behaviour.

This leads to the conclusion that there is a significant association between the information seeking behaviour of guava growers and their education level, social participation, size of land holding, farm power, innovation proneness and annual income. Age, family size and farming experience of distant guava growers were non-significantly associated with their information seeking behaviour, which leads to 
the conclusion that there is no significant association between the information seeking behaviour of distant guava growers and their age, family size and farming experience. The results are in accordance with the results obtained by Meena and Sisodiya (2009), Murari and Singh (2011) and Jaisridhar et al., (2015)

The study leads to the conclusion that majority (76 per cent) of both type of guava farmers. i.e. peripheral and distant were having medium level of information seeking behaviour followed by 13 per cent having low and only 11 per cent were having high level of information seeking behaviour. The value between the scores of the information seeking of the peripheral and distant guava farmers was -0.74 , which was non-significant. This shows that there was no significant difference between the peripheral and distant guava farmers in their information seeking behaviour.

The study also reveals that there was significant association between the information seeking behaviour of total guava farmers (both peripherals and distant) and their age, education level, social participation, size of land holding, farm power, innovation proneness and annual income.

Similarly non-significant association was found between the information seeking behaviour with the family size and farming experience of guava farmers.

\section{References}

Dhayal, B. L., Khan I. M. and Jangid M. K. 2009. Association of the information seeking behavior of the Ber growers of Jaipur district of Rajasthan M.Sc. (Ag.) Thesis RAU, Bikaner, Campus Jobner.

Jaisridhar, P., Sankhla, G., Kadian, K. and Sangeeta, S. 2015. Socio economic determinants of dairy farmers and their correlates with adoption of scientific dairy farming information delivered through farmers call centers. Indian Journal of Social Research vol. 56 (2) (March-April) 282-287.

Meena D.K., Bareth, L.S. and Badhala, B.S. 2013. Association between knowledge level of respondents about coriander production technology. Journal of Progressive Agriculture, Vol. 4 No. 1, April pp 1-3.

Meena, B.L. 2012: Technological gap in Guava production in Bundi district of Rajasthan. M.Sc. Ag. Thesis SKRAU, Bikaner Campus-Jobner.

Meena, S.R. and Sisodia, S.S, 2003: Knowledge levels of farmers about improved Guava production practices, Raj. J. Ext. Edu., Vol. 13: 71-76.

Murai, A. S. and Singh B. K. 2011 Differential adoption of scientific dairy farming practices and related constraints. Indian Research Journal of Extension Education 11 (2): 46-49

Sharma, K.C. and Mitharwal B.S. 2011: Technological gaps and suggested strategies to boost Guava production technology Raj. J. Ext. Edu. 19:182-184

\section{How to cite this article:}

Sharma, K.C., Seeta Bijarniya, Rajendra Junjadiya and Shalini Sharma. 2017. Information Seeking Behavior of Tribal Guava Farmers in Sawai Madhopur District of Rajasthan. Int.J.Curr.Microbiol.App.Sci. 6(11): 3441-3445. doi: https://doi.org/10.20546/ijcmas.2017.611.405 